\title{
Reliable yields of public water-supply wells in the fractured-rock aquifers of central Maryland, USA
}

\author{
Patrick A. Hammond ${ }^{1}$
}

Received: 16 January 2017 / Accepted: 3 July 2017 / Published online: 28 July 2017

(C) The Author(s) 2017. This article is an open access publication

\begin{abstract}
Most studies of fractured-rock aquifers are about analytical models used for evaluating aquifer tests or numerical methods for describing groundwater flow, but there have been few investigations on how to estimate the reliable long-term drought yields of individual hard-rock wells. During the drought period of 1998 to 2002, many municipal water suppliers in the Piedmont/Blue Ridge areas of central Maryland (USA) had to institute water restrictions due to declining well yields. Previous estimates of the yields of those wells were commonly based on extrapolating drawdowns, measured during short-term singlewell hydraulic pumping tests, to the first primary water-bearing fracture in a well. The extrapolations were often made from pseudo-equilibrium phases, frequently resulting in substantially over-estimated well yields. The methods developed in the present study to predict yields consist of extrapolating drawdown data from infinite acting radial flow periods or by fitting type curves of other conceptual models to the data, using diagnostic plots, inverse analysis and derivative analysis. Available drawdowns were determined by the positions of transition zones in crystalline rocks or thin-bedded consolidated sandstone/limestone layers (reservoir rocks). Aquifer dewatering effects were detected by type-curve matching of step-test data or by breaks in the drawdown curves constructed from hydraulic tests. Operational data were then used to confirm the predicted yields and compared to
\end{abstract}

P. A. Hammond is formerly with the Maryland Department of the Environment.

Electronic supplementary material The online version of this article (doi:10.1007/s10040-017-1639-4) contains supplementary material, which is available to authorized users.

Patrick A. Hammond

phammond@broadstripe.net

1 Severna Park, MD 21146, USA regional groundwater levels to determine seasonal variations in well yields. Such well yield estimates are needed by hydrogeologists and water engineers for the engineering design of water systems, but should be verified by the collection of longterm monitoring data.

Keywords Hydraulic testing · Water supply $\cdot$ Fractured rocks $\cdot$ Well yield $\cdot$ USA

\section{Introduction}

The state of Maryland is located in the Mid-Atlantic region of the eastern United States, and has a wide range of geology and aquifer types. Wells in the aquifers typically vary from high yielding ones (commonly more than $1,500 \mathrm{~L} / \mathrm{min}$ ) in confined and unconfined, unconsolidated sandstone layers on the eastern shore and southern Maryland to relatively low yielding ones (generally less than $300 \mathrm{~L} / \mathrm{min}$ ) in the fractured rock areas of the Piedmont, Blue Ridge, Valley and Ridge, and Appalachian Plateau provinces of central and western Maryland. The state includes much of the major Washington-Baltimore metropolitan complex where about 5 million people live. Most of the metropolitan area is served by surface water from the Potomac River and the Baltimore City reservoir system. Some of the fastest growing suburban areas, however, are located in the Piedmont and Blue Ridge areas, and many are supplied by wells in fractured rock aquifers or small reservoirs.

There was a prolonged drought in the state during the period 1998-2002, culminating in one of the three worst droughts on record; the others occurring in 1930-1932 and 1962-1969. The major surface-water suppliers in the metropolitan area had little difficulty meeting customer demand, due to substantial reservoir storage facilities. Many of the small-to-medium-size towns (populations less than 10,000 
people), however, were required to institute voluntary or mandatory water restrictions, due to declining well yields.

Hydraulic and aquifer tests that run for 24-72 $\mathrm{h}$ have been a requirement for water use permit evaluations by the Maryland Department of the Environment (MDE) for several decades, during which MDE compiled the results of several hundred aquifer tests in the fractured rock region of Maryland. A method commonly used in Maryland, prior to the early 1990s, was to conduct a single-well hydraulic test in such a manner that stabilization of the water level in a pumping well was achieved, either by producing an apparent equilibrium at a constant rate or by reducing the pumping rate as the test proceeded, then extrapolating the drawdown data to the first primary water-bearing fracture in a well for a 30-day period to meet maximum monthly demand. A review was completed by MDE of production and monitoring records-shown in Table S1 in the electronic supplemental material (ESM) - collected during the 1998-2002 drought from 97 wells and 2 springs of municipal purveyors and a few golf courses in the fractured rock areas of central Maryland. That study indicated that the average maximum drought production was only $54 \%$ of the estimated yields using the techniques then in common use, but $83 \%$ of the estimates made using the methods developed in the present study. The present study is focused on developing methods for improving the estimates of reliable well yields in the fractured rock aquifers of Maryland. Results from pumping and step tests, well characteristics, drought and non-drought production and water use information, general and site-specific geological features, and regional and local groundwater levels are presented. Summaries of the well characteristics and the results of the analyses of the step and pumping test data are shown in Tables S2, S3 and S4 of the ESM.

A review of the literature found that most publications on fractured rock aquifers were studies on contaminant transport, models developed for deriving hydraulic constants from aquifer test data, or concerning safe yields of aquifers on a watershed or regional basis. There were few studies, however, that developed methods for directly predicting reliable yields of individual hard rock wells.

Parizek and Siddiqui (1970) tested wells in carbonate aquifers in State College, Pennsylvania (USA), and stated that well yields are determined by the position of the water table relative to producing zones. For those wells with available data, the production was an average of $61 \%$ of the estimated yield.

Daniel (1990) proposed techniques for maximizing sustained yields for wells of a municipal supply completed in Piedmont crystalline rocks. After implementation of an 18-h on and 6-h off daily schedule, total daily production was $60 \%$ of the anticipated yield of the municipal well field.

Misstear and Beeson (2000) used operational data to establish reliable yields in a shallow, unconfined, fissure flow (UK Chalk) aquifer. Their calculations were based on extrapolation of drawdowns using the Cooper-Jacob (1946) straight-line method and assuming 200 days of continuous pumping, during a dry summer under average demand conditions. The drawdowns at $100 \mathrm{~min}$ from step-test data (for well losses) were then added, to produce a total drawdown at the depth of the first water strike. No yields were directly predicted, because the results were achieved by fitting yield curves to existing operational data.

Van Tonder et al. (2001a) used derivative analysis and semi-analytical techniques to develop their flow characteristic method (FC-method) for estimating yields of wells in the layered, sedimentary rock (multi-porous) Karoo aquifer of South Africa. Using data from a test of well UO5 at an extensively monitored research test site, they conducted a numerical analysis to verify their model, where the available drawdown was related to the depth of a single, discrete horizontal fracture. Van Tonder et al. (2001b) proposed that natural fractures may close over time, due to deformation of an aquifer as water levels in a well decline. Although these were comprehensive studies, no operational data were presented to confirm the researchers' estimates of long-term well yields.

Piscopo and Summa (2007) conducted a 1-year, constant drawdown test of a carbonate rock well and recommended limiting drawdown to $12 \mathrm{~m}$, based on the results of a steptest of the well analyzed using the Jacob (1947) method. Their estimated yield $\left(0.94 \times 10^{-3} \mathrm{~m}^{3} / \mathrm{s}\right)$ was a fraction of the production $\left(2-5 \times 10^{-3} \mathrm{~m}^{3} / \mathrm{s}\right)$, which reflected the result of seasonal variations during the year-long test. The higher yields were confirmed by a follow-on numerical model developed by Baiocchi et al. (2014).

\section{Methods}

\section{Analytical techniques}

A common method for analyzing pumping test data is to use graphical type-curve matching techniques developed for various analytical models. The one most frequently applied is the two-dimensional radial flow solution developed by Theis (1935). Renard (2009) indicated that the late-time CooperJacob (1946) straight line solution, with a constant derivative, supports the infinite acting radial flow (IARF) assumption of the Theis model. Others are those depicting: linear/pseudoradial flow (Gringarten et al. (1975)) for single vertical and horizontal fractures (SVF and SHF); pseudo-equilibrium and delayed yield effects (Boulton 1954; Neuman 1972 and Strelsova 1976); generalized radial flow in single- and double-porosity fractured aquifers (Barker 1988); and leaky aquifers (Hantush (1960) and Moench (1985) . Dual-porosity responses have been described by Moench (1984) and Dougherty and Babu (1984); however, Odeh (1965) and 
Carlson (1999) have indicated that they may be scale dependent.

These graphical methods are prone to errors in individual judgment, because different flow models can provide relatively good visual fits to the same set of data. Computer-assisted inverse analysis techniques, the process by which a theoretical curve is numerically fitted to a data set, is generally regarded as less subject to individual bias; however, both methods are non-unique where there are multiple plausible solutions. Most of the published work consists of programs designed to match test data to one or a few analytical models; however, while not endorsing the product, the commercially available AQTESOLV program (Duffield 2007), used in the present study, includes 35 different analytical models, many of which can be applied to fractured rock aquifers.

The primary tool for the derivative analysis method is a simultaneous plot of drawdown and the logarithmic derivative of drawdown as a function of time. It is now considered the best method for identifying an appropriate conceptual model to use when analyzing aquifer test data (Samani et al. 2006). Renard et al. (2009) provides a synthesis of the behaviors of typical drawdown and log derivative plots in response to constant pumping rates. Derivative analysis of drawdown is applied to single-well tests to assess the influence of well-bore storage, type of aquifer, presence of boundaries, and flow regimes in the data.

Even with the advantage of an inverse analysis, various models could provide similar fits to specific sets of drawdown data. Knowledge of the hydrogeology of the site, application of diagnostic plots and derivative analysis, and calculated residuals from the curve-fitting process may help select the correct conceptual model for a set of time-drawdown data. There follows a brief review of the conceptual models, derivative analysis methods and automatic curve-fitting techniques used in the present investigation. A further detailed discussion, including mathematical derivations, is contained in the Hammond and Field (2014) study.

Jacob (1947) introduced the step-drawdown test to determine well performance, indicating that where turbulent flow exists, drawdown, $s$, equals the sum of a first-order (laminar) component and a second-order (turbulent) component. Mogg (1969) indicated that reductions in specific capacity as discharge rate increases may be due to some factor other than turbulent flow. Pumping of fractured-rock wells under watertable (unconfined) conditions, where there is a major reduction in saturated thickness, can introduce other such head losses. The Theis method can be applied to these types of aquifers, when drawdown is small relative to saturated thickness or corrected using the Jacob (1944) formula. The CooperJacob (1946) method can simulate variable-rate tests by using the deconvolution algorithm developed by Birsoy and Summers (1980). For the typical step-test, this is most easily performed using an automatic curve-fitting program. The
AQTESOLVTM program modifies the Dougherty-Babu (1984) solution by a term for nonlinear well loss in a confined dual porosity aquifer, and adds terms for linear and nonlinear well losses to the Theis (1935) and Hantush-Jacob (1955) solutions for pumping in a confined aquifer and a leaky confined aquifer, respectively.

While a three-dimensional (3D) numerical model may be the best method for estimating well yields in fractured rock aquifers, an Internet search indicates that only one state governmental agency in the USA is known to require them, and only as a third option, after use of the Theis method and image well theory. Most (30) states do not have regulations or published guidance documents that include detailed instructions on how to estimate well yields but, as Maryland does, they may develop specific test and evaluation procedures during the water use permitting process. Five states use a 180 -day time period when extrapolating drawdowns to determine yields. One USA state and British Columbia (Canada) use a 100-day time period, while another USA state and Alberta (Canada) use a 20-year time period. Some other methods are based on achieving a stabilized pumping rate (five USA states) or using some fraction equal to or greater than the capacity of the well pump (five states).

Over the past 30 years ago, Maryland state government and consulting hydrogeologists have developed a method to determine reliable well yields in fractured rock aquifers. The developed method assumes that the reliable yield of a fractured rock well in a humid area such as the mid-Atlantic region of the eastern United States, is not a direct function of long-term average recharge, but is related to a critical $\sim 90$-day period during a severe drought, when demand is at its highest, recharge is negligible and groundwater availability is at its lowest level. During a 90-day period of drought, the maximum monthly demand also could occur over a period as much as 60 days and adding 30 more days would provide a margin of error. It follows that the calculated long-term well capacity is sustainable over the long term, and that aquifer recharge would occur and pumping demand would be reduced during the off-season.

Support for the extrapolation period is provided by Schultz et al. (2005), who defined summertime (or third quarter, 92 days) water availability as the sum of beginning-of-summer groundwater storage and summer recharge. They indicated that within the area of the present study, summertime groundwater availability is lowest in the upper Monocacy sub-basin (Mesozoic lowland), consisting primarily of consolidated sedimentary rocks, dropping to below $0.10 \mathrm{in}$. $(2.6 \mathrm{~mm})$ during the drought period of the mid-1960s and also in 2001, and is also low in the Catoctin sub-basin (Middletown Valley) in the Blue Ridge Provence, consisting mostly of crystalline rocks, dropping to below 0.15 in. $(3.8 \mathrm{~mm})$ in 1965 and in 2002. 
Reliable yield is defined as the pumping rate of a well that can supply the maximum monthly demand of a municipal water supply under drought conditions and would not cause the water level in the well to drop below a prescribed level, or the available drawdown $\left(s_{\mathrm{A}}\right)$ in the well needed to maintain the long-term sustainable yield of the well. When estimating reliable yields, drawdowns $\left(s_{\mathrm{t}}\right)$ are first extrapolated to a prescribed time (t) of 90 days on a semi-log graph, using the Cooper-Jacob straight-line method or an appropriate type curve, if an IARF period cannot be identified. The specific capacity $\left(Q_{\text {obs }} / s_{\mathrm{t}}\right)$ at that point is calculated, using the continuous pumping test rate $\left(Q_{\text {obs) }}\right.$. The result is then applied to the $s_{\mathrm{A}}$ in order to produce the reliable yield $\left(Q_{\mathrm{R}}\right)$ as expressed in the form of Equation 10 in van Tonder (2001a):

$Q_{\mathrm{R}}=\left(Q_{\mathrm{obs}} / s_{\mathrm{t}}\right) s_{\mathrm{A}}$

If well losses occur, the yield can be adjusted by subtracting the losses from $s_{\mathrm{A}}$.

The results of methods used in the present study were compared to those achieved using the calibrated 3D numerical model developed by van Tonder et al. (2001a) to verify the estimated sustainable yield of a fractured rock well (UO5). The geometry of the model was based on the hydraulic characteristics of the Karoo aquifer at the Campus Test Site, which were derived from data collected during an extensive field investigation. A recharge rate of $15 \mathrm{~mm} /$ year. and a pumping period of 1 year were applied, producing a sustainable yield of $0.41 \mathrm{~L} / \mathrm{s}$ (or as later changed to $0.48 \mathrm{~L} / \mathrm{s}$ by van Tonder et al. 2001b). The result was similar to the $0.36 \mathrm{~L} / \mathrm{s}$ estimated by their FC-method; except, in that case, the pumping period was assumed to be 2 years.

Using the Barker (1988) generalized, single- and doubleporosity, radial flow type curve, drawdowns from the Karoo pumping test were extrapolated in the present study (Fig. S3 of the ESM) to 90 days, 200 days, 1 and 2 years, reflecting pumping periods used in the present study, by Misstear and Beeson (2000) and by van Tonder et al. (2001a) for the Karoo model and FC-method, respectively. The calculated specific capacity at the end of each pumping period was applied to the available drawdown of $6 \mathrm{~m}$, producing yields of $0.69,0.58$, 0.51 and $0.44 \mathrm{~L} / \mathrm{s}$, respectively. Typical ratios for municipal water demand in Maryland are 1.4:1 for maximum monthly use and 1.15: 1 for summertime seasonal water demands relative to annual average use. These ratios are based on internal reports of the MDE (Patrick A. Hammond, unpublished memorandums dated 15 November 2004 and 21 April 2010, see ESM), which are consistent with those contained in various water supply engineering studies such as the American Water Works Association's Manual M1 (AWWA 2000; Billings and Jones 2008). When these ratios were applied to the seasonal periods, the estimated equivalent yearly average yields are both $0.5 \mathrm{~L} / \mathrm{s}$, while the long-term average yields are
0.51 and $0.44 \mathrm{~L} / \mathrm{s}$, demonstrating that similar results were achieved when seasonal variations in water demand were considered.

\section{Location of study area}

Figure 1 is a map of central Maryland, showing the locations of the sites involved in the present study. The general area consists of three suburban counties in the BaltimoreWashington Metropolitan Complex: Carroll, Frederick and Montgomery Counties. The aquifer test and well production data were collected from the municipal water supplies of Emmitsburg, Thurmont, Point of Rocks, Poolesville, Westminster, and Taneytown. These cases were chosen because they demonstrate characteristic responses to pumping and have long-term operational data that could be used to support the actual reliable yields of the wells.

\section{General geology}

The study area, located in central Maryland, consists of parts of the Blue Ridge and the western Piedmont physiographic provinces. The Piedmont portion of this area has been divided into the upland Piedmont and Mesozoic Lowland subprovinces. The rock types generally consist of carbonates and consolidated sedimentary rocks in the central lowland areas, and igneous and metavolcanic rocks along the eastern flank of the study area and the Blue Ridge Mountains to the west.

The upland Piedmont is largely underlain by Precambrian and Cambrian metamorphic and igneous rocks, primarily phyllites and schists. The phyllitic rocks are intermingled with other metavolcanics, and in the Wakefield Valley, carbonate rocks. The Mesozoic Lowland consists of Triassic sedimentary rocks, which are primarily interbedded siltstones, sandstones, and limestone conglomerates, and Jurassic igneous intrusions. Most of the floor of the Frederick Valley is underlain by limestone rocks. The Blue Ridge rocks are principally Late Precambrian metavolcanic rocks, with minor quartzite, phyllite, shale and carbonate units. A detailed discussion and map of the geology of the study area are provided in the ESM.

Harned and Daniel (1992) developed a conceptual profile of a Piedmont crystalline rock aquifer (Fig. S2 of the ESM). They indicated that the regolith consists of saprolite, soil and alluvium, and contains most of the groundwater stored in crystallinerock aquifers. Maximum porosity occurs near the contact or transition zone between the regolith and unweathered bedrock. The regolith exists under water-table conditions and is hydraulically coupled to locally confined bedrock. As depth increases, lithostatic pressure tends to close fractures, such that total porosity typically is less than $1 \%$. Well casings are now drilled through the weathered zone and set in competent bedrock, to produce turbidity-free water. Otten (1981) constructed a 


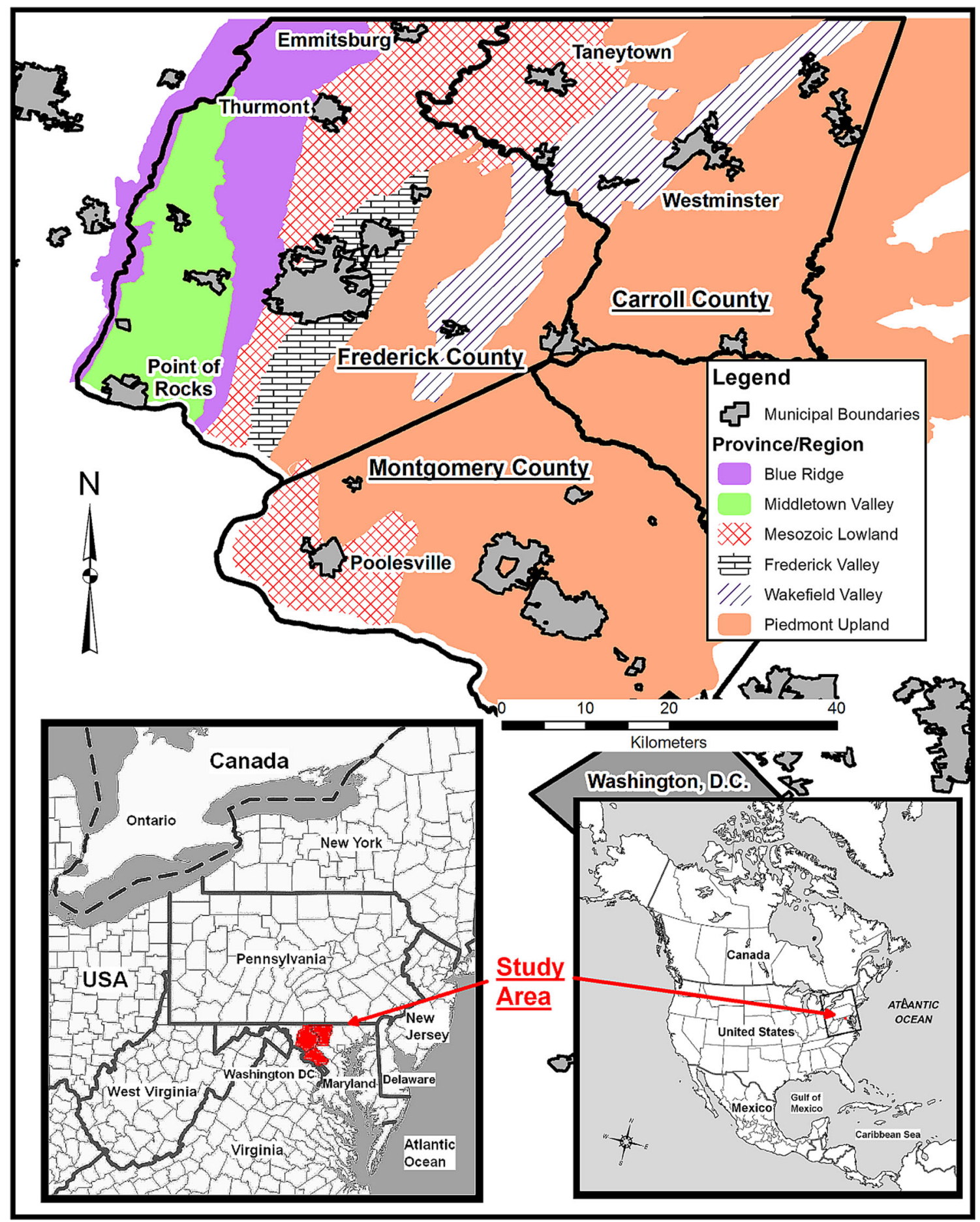

Fig. 1 Location map. Central Maryland study area

hydrogeologic cross section (Fig. S11 of the ESM) of the Triassic New Oxford Formation in the vicinity of Poolesville, Maryland. The residuum in Triassic-rock aquifers can be thin and may not extend below the zone of saturation. The mean porosity of Triassic sandstones and conglomerates can be quite high due to secondary solution of calcite cementing materials. Porosity is higher and fracture development greater than the typical Piedmont crystalline rock aquifer.

\section{Results}

Emmitsburg well 3

Well 3 of the town of Emmitsburg was completed in the crystalline rock Catoctin Metabasalt. This project was the prototype where the methods in the present study were initially developed and first applied. A 9-day (13-22 November 
Fig. 2 Emmitsburg well 3: Semi$\log$ plot of drawdown data from a step-test and 9-day pumping test, with estimated yields from drawdowns extrapolated to 90 days, and drought production. $s$ drawdown, $s w l$ static water level, bTOC below top of casing, $M w b z$ major (or primary) water-bearing zone. The well is located $20 \mathrm{~m}$ from a raw water reservoir. Average water use (L/min) during the drought year of 2001 relative to pumping drawdowns are shown for the months of June, September and November

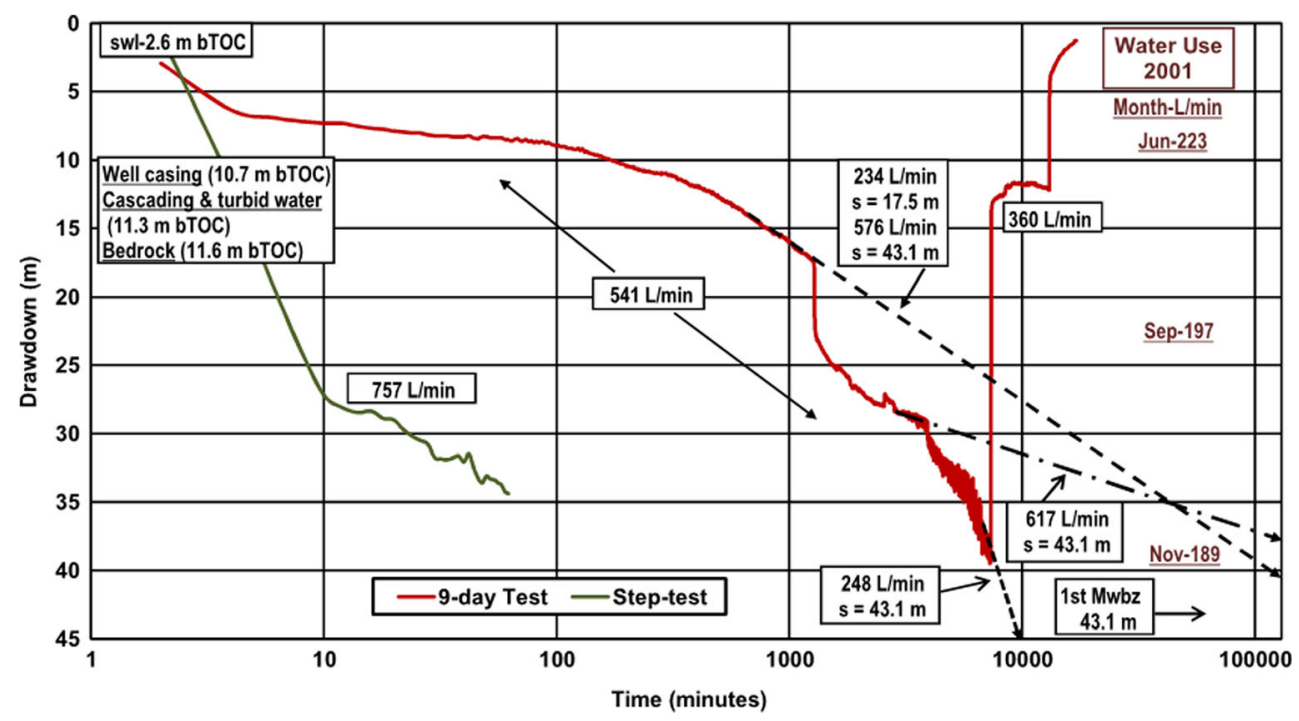

1996) pumping test of that well was conducted, with followup monitoring of water levels and daily production. Figure 2 is a semi-log plot of drawdown vs time for that test, which was started at $541 \mathrm{~L} / \mathrm{min}$, at an initial or static water level (swl) of $2.6 \mathrm{~m}$ below top of casing (bTOC) or the measuring point. At first glance, the drawdown observed during the first $8 \mathrm{~h}$ of the test appears to be due to a delayed yield response in a watertable aquifer. A derivative analysis (Figure 3) indicated that the early drawdown, after depletion of well-bore storage, was affected by a constant head or intermittent recharge boundary. This was supported by reports of high turbidity and cascading water at the level where the transition zone could occur. The source of the turbid water was probably from an abandoned, unlined, off-stream, raw-water reservoir, with a limited storage capacity and drainage area, located $20 \mathrm{~m}$ from the well. Operators had reported that the pond level dropped as water was pumped from well 3. Most likely, the transition zone acts as a conduit between the pond and the wellbore. This observation is supported by operator reports that the turbidity of the water in the well clears up a few hours after pumping is started, which could be related to dewatering of the weathered zone and breaking of the hydraulic connection between the pond and the well.

The next phase of the test was a water-table response, followed by an IARF segment which lasted for the next $13 \mathrm{~h}$. At the end of the IARF period and at a point about $4.6 \mathrm{~m}$ below the casing, or a drawdown of $17.5 \mathrm{~m}$, there was a sharp break in the drawdown data. The change in slope appears to have occurred at the weathered zone/bedrock interface, and was probably due to a sharp reduction in permeability. (Note: This break was not observed during the stepdrawdown test, due to rapid dewatering of the aquifer). It was followed by a pseudo-equilibrium phase, which is attributed to leakage and lasted for about 2 days. Had the test ended at this point, the conventional wisdom would have been that it was a very high-yielding well. The test, however, was
Fig. 3 Emmitsburg well 3: Semi$\log$ plot of logarithmic derivative of drawdown from the first 5 days of the 9-day test. The well is located $20 \mathrm{~m}$ from a raw water reservoir

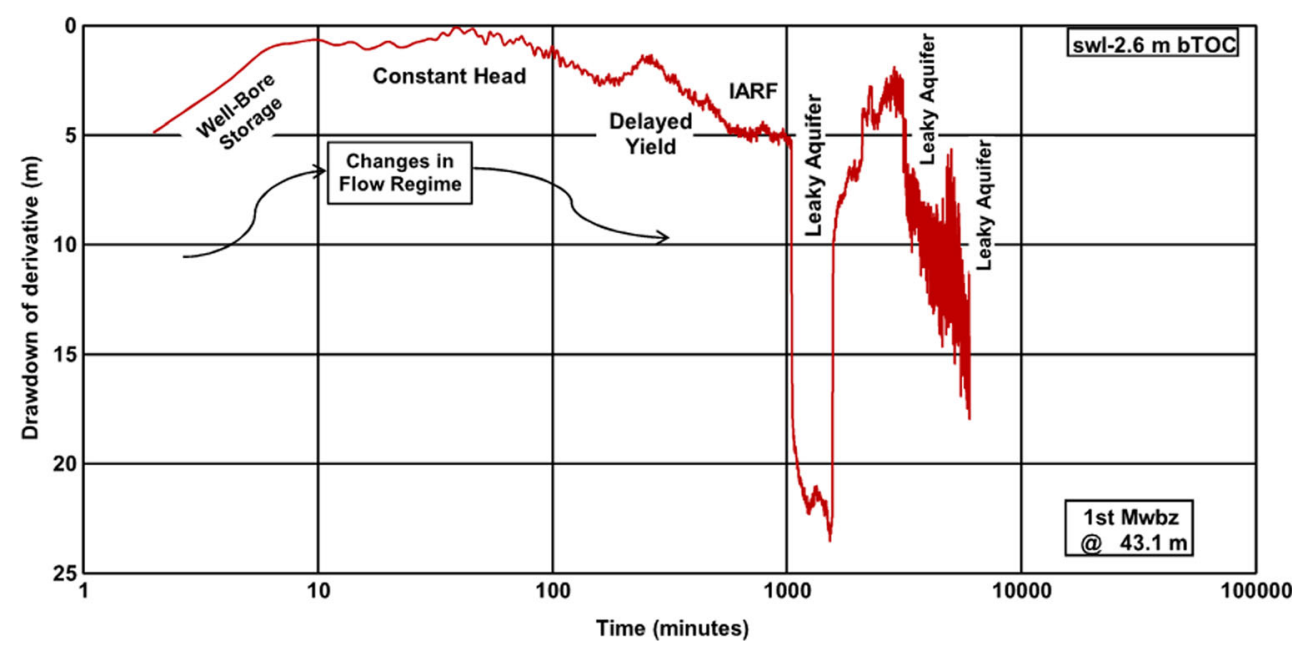


Fig. 4 Emmitsburg wells 3 and 5: Reported water use and water levels in USGS monitoring well FR Bd 96, and 3-month moving averages, with FR Bd 96 groundwater levels $(G W L)$ shifted forward by 4 months

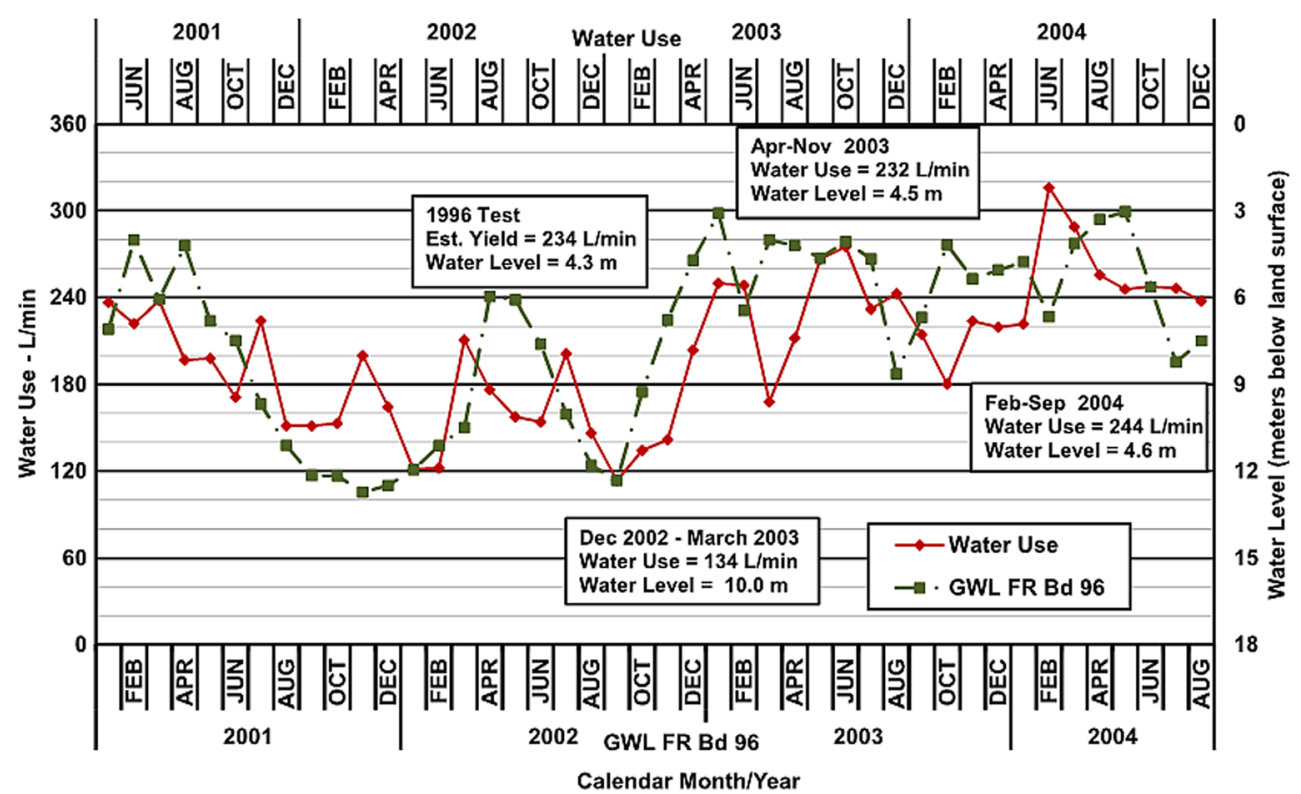

continued for several more days, during which the drawdown increased rapidly through two other leaky aquifer phases, until the water level approached the major water-bearing zone (Mwbz), at which time the test was secured. After $25 \mathrm{~h}$ of recovery, the test was re-started at $360 \mathrm{~L} / \mathrm{min}$, the water level stabilized, and the test finally ended after nine days of pumping.

The available geologic and pumping test data indicate that the casing for well 3 was set above the transition zone, a common method used by drillers to potentially increase well yields when the well was completed in 1965 (but is not presently allowed, to prevent surface-water contamination). This produced a short circuit between the weathered zone and bedrock portions of the aquifer, which was by-passed upon dewatering of the weathered zone. Groundwater flow was then by leakage from the weathered zone to the discrete, main, water-bearing fracture and from there to the wellbore.

Towards the end of the test, rapid fluctuations in the water level began to occur. Kawecki (1995) suggested that small, practically immeasurable changes in discharge can cause significant changes in drawdowns, if well losses are high. Another possible explanation is based on a similar response noted during a recent test in Poolesville. In that case, manual measurements with an electric probe indicated that the water levels were actually stable and that pump vibrations on the PVC measuring tube probably affected the pressure recorded by the transducer of the automatic data logger in use.

This test was conducted under very wet climatic conditions. Based on preliminary studies, it was estimated that the well could produce about one-half of the final test yield during a severe drought, or $189 \mathrm{~L} / \mathrm{min}$. On the right hand side of Fig. 2 are the production and water levels measured in the well during the drought of 2001-2002, which confirmed that the well could only produce $189 \mathrm{~L} / \mathrm{min}$ during the worst part of the drought (November 2001).

During preparation of this report, the test data in Fig. 2 were used to make estimates of the well's yield by extending a straight-line from various parts of the drawdown curve to 90 days. The specific capacity $(Q / s)$ at that point was determined and then applied to values of available drawdown. From the IARF period, the estimated yield was $234 \mathrm{~L} / \mathrm{min}$, when the extrapolated $Q / s$ is multiplied by the available drawdown to the breakpoint (weathered zone/bedrock interface) in the data, or $576 \mathrm{~L} / \mathrm{min}$ using the available drawdown to the first major water-bearing zone. Extrapolations from the later parts of the curve produced estimates of 248-617 L/min. The production data indicate that the estimated value of $234 \mathrm{~L} / \mathrm{min}$ was closest to the final reliable yield.

Figure 4 is a graph of monthly production and regional water levels plotted against time, for the drought of 20012002 and the following very wet period of 2003-2004. The regional water levels were measured in a monitoring well (FR Bd 96) of the US Geological Survey, located $12.4 \mathrm{~km}$ southwest of Emmitsburg well 3. That well has the largest range of water levels of any USGS monitoring well in the fractured rock areas of Maryland, which is believed to be due to the lack of aquifer storage in the vicinity of that well and a strong hydraulic connection to the shallow portion of the aquifer. Emmitsburg well 5 was placed in service during early 2003. Due to the relatively low estimated yield $(<75 \mathrm{~L} / \mathrm{min})$ and interference caused by close proximity $(50 \mathrm{~m})$ to well 3 , it was expected that well 5 would have added little to the reliable yield of the system. Both wells were run continuously ( $24 \mathrm{~h} /$ day) to accommodate this specific study and to eliminate the need to estimate the effects of a variable pumping period. The production from the wells $(232-244 \mathrm{~L} / \mathrm{min})$ when regional 
Fig. 5 Emmitsburg well 3: Semilog plot of drawdown from the step-test; data are both uncorrected and corrected for an aquifer thickness $(b)$ of $17.5 \mathrm{~m}$. RSS sum of the squared residuals

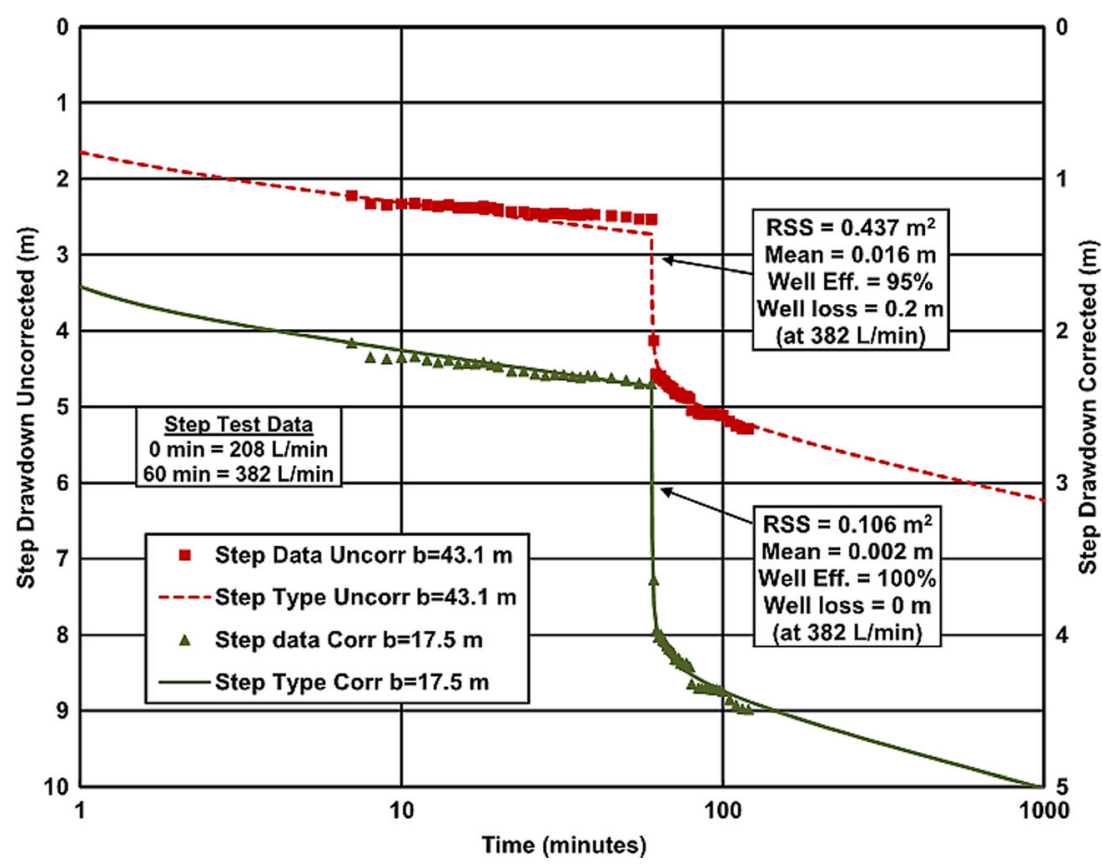

water levels are the same as those during the 1996 test was equal to the estimated yield $(234 \mathrm{~L} / \mathrm{min})$. These data indicated that the maximum monthly amount of water produced was about three times the minimum monthly amount. A limited amount of water may have leaked from the raw-water reservoir during wet periods; however, the pond was dry during the drought. In addition, there was a good correlation between the regional water levels and well production when the regional water levels were offset (shifted forward) by 4 months. This indicates that there is a delayed effect of drought or high recharge events on the sustained yield of the wells, probably due to changes in aquifer storage and leakage to the depressed water table.

The step-test data collected from Emmitsburg well 3 were generally unsuitable for analysis since there were three separate tests consisting only of two steps each, which were conducted over a period of several weeks. Half of the steps were influenced by complete dewatering of the transition zone with water levels ending up in bedrock such as the one shown on the semi-log plot (Fig. 2). The other three steps at 208 and $382 \mathrm{~L} / \mathrm{min}$ (test 1), and $568 \mathrm{~L} / \mathrm{min}$ (test 2), if corrected for dewatering of the aquifer, produced a difference in specific capacities of $12 \%$, with the last rate being higher than the well's reliable yield.

Figure 5 is a semi-log plot of the first two steps from test 1 , with drawdowns both uncorrected and corrected for aquifer thickness $(b)$. The AQTESOLV ${ }^{\circledR}$ software for analysis of aquifer tests (Hydrosolve, Inc. 2007) uses a modified version of the deconvolution methods contained in Birsoy and Summers (1980) that allows automated fitting of type curves to step-test data. Application of the modified Dougherty-Babu (1984) solution to the data from the uncorrected $(b=43.1 \mathrm{~m}$ or the drawdown to the first major water-bearing fracture) steptest data produced fairly good results, with a sum of squared residuals (RSS), where a residual is the difference between the observed and simulated value, of $0.437 \mathrm{~m}^{2}$ and a mean of $0.016 \mathrm{~m}$; and, at the last rate of $382 \mathrm{~L} / \mathrm{min}$, a well efficiency of $95 \%$ and well loss of $0.2 \mathrm{~m}$. The best fit to the data, however, was achieved by correcting the data for the effects of dewatering, using a $b$ value of $17.5 \mathrm{~m}$. This produced a RSS of $0.106 \mathrm{~m}^{2}$ and a mean of $0.002 \mathrm{~m}$; and, at $382 \mathrm{~L} / \mathrm{min}$, a well efficiency of $100 \%$ and a well loss of $0.0 \mathrm{~m}$.

\section{Poolesville well 7 and water system production data}

The town of Poolesville's municipal wells were all completed in consolidated sedimentary rocks of the Triassic New Oxford Formation. The results of a step-test performed on well 7 are shown in Fig. 6. Initially it was assumed that the saturated thickness (b) was $128 \mathrm{~m}$, based on the drawdown to a single major water-bearing fracture in the well. Application of the AQTESOLV modified Dougherty-Babu (1984) solution for step-drawdown tests produced poor results $\left(\right.$ RSS $=1,456 \mathrm{~m}^{2} ;$ mean $\left.=-0.15 \mathrm{~m}\right)$ using that value of $b$. By iterative methods, the drawdown data were corrected for dewatering effects, with a good match achieved by using a $b$ value of $88 \mathrm{~m}\left(\mathrm{RSS}=25.4 \mathrm{~m}^{2}\right.$; mean $\left.=-0.006 \mathrm{~m}\right)$. Upon close review of the geologic log for the well, it was noted that virtually all of the rock penetrated by the well was shale, except for a limestone/sandstone sequence between 55 and $91.4 \mathrm{~m}$ and a thin-bedded limestone near the single waterbearing zone (wbz). After correcting for the effects of aquifer dewatering, the calculated well efficiency was $99.7 \%$ and the well loss was $0.01 \mathrm{~m}$. 
Fig. 6 Poolesville well 7: Semi$\log$ plot of drawdown from steptest; data are both uncorrected and corrected for aquifer thickness $(b)$ of $88 \mathrm{~m}$

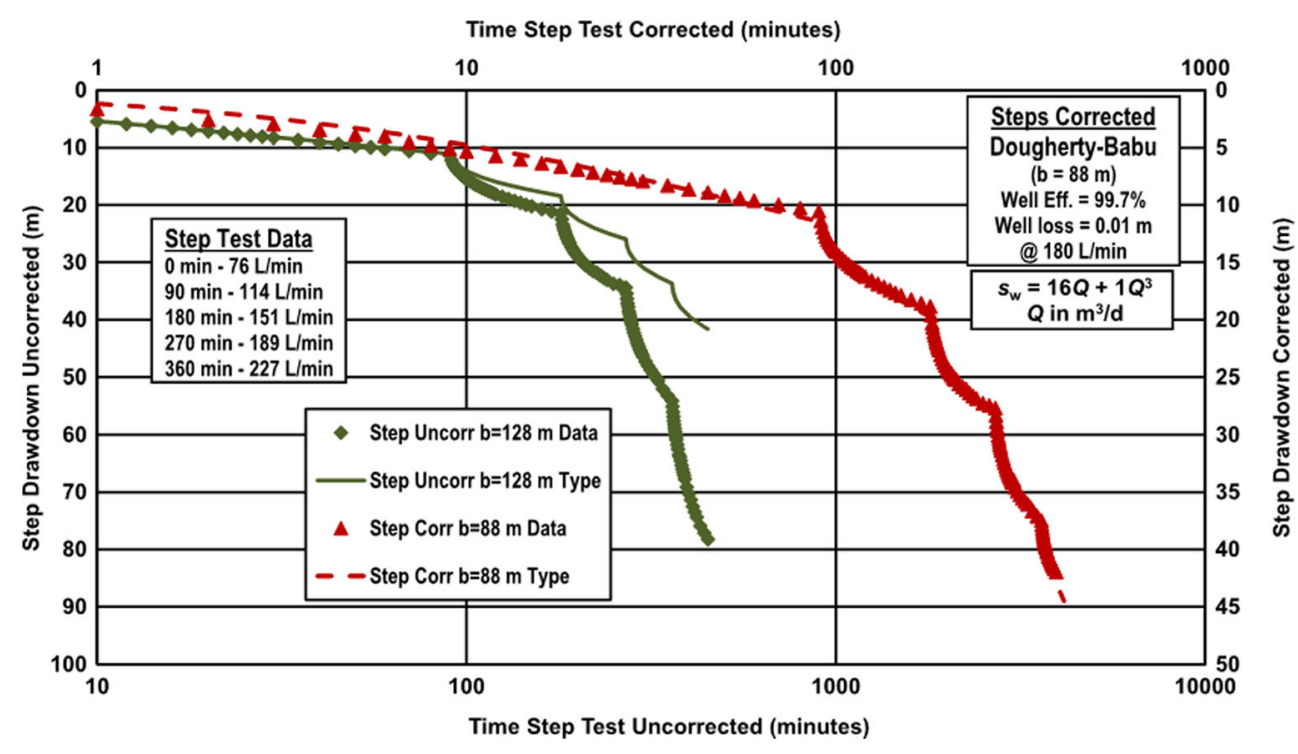

By comparison, an arithmetic plot of $s_{\mathrm{w}} / Q$ versus $Q$ (Fig. 7) produced a good fit to the Jacob (1947) model according to the following expression:

$s_{\mathrm{w}}=0.047 Q+0.001 Q^{2}$

At the demonstrated reliable average daily production of at least $156 \mathrm{~L} / \mathrm{min}$ from well 7 , the calculated well efficiency using the Jacob equation would be $29.3 \%$. To obtain a relatively highly efficient well $(80.6 \%)$ would require the well to be pumped at a rate of $90 \%$ less than the demonstrated reliable yield. These results indicate that an apparently inefficient well was actually an efficient one that was affected by aquifer dewatering during the step-test.

In preparation for this report, derivative and type curve analyses of the pumping test data were performed and the results are shown in Fig. 8. There was no clear IARF period present during the 1999 72-h hydraulic test and the Moench leaky aquifer conceptual model best fit the data, until the drawdown reached $70 \mathrm{~m}$ at 2,040 min. At that point, there was a break in the slope, probably due to dewatering of a permeable unit. These observations, the production data, and the results from the step-test indicate that the depth to a permeable unit within the 55-91 m limestone/sandstone interval, not the depth to the 131-m water-bearing fracture, controls the available drawdown. These results demonstrate that the reliable yield of the well was less than the test rate of $189 \mathrm{~L} / \mathrm{min}$, but more than the maximum production rate of $156 \mathrm{~L} / \mathrm{min}$.

A flow control valve was installed in well 7 to help maintain relatively constant operating water levels in the well. During a follow-on test, the well was pumped continuously for 60 days ending in December 2009, producing a sustained
Fig. 7 Poolesville well 7: Arithmetic plot (Jacob method) of specific drawdown $\left(s_{\mathrm{w}} / Q\right)$ and discharge $(Q)$ for the step-test data shown in Fig. 12

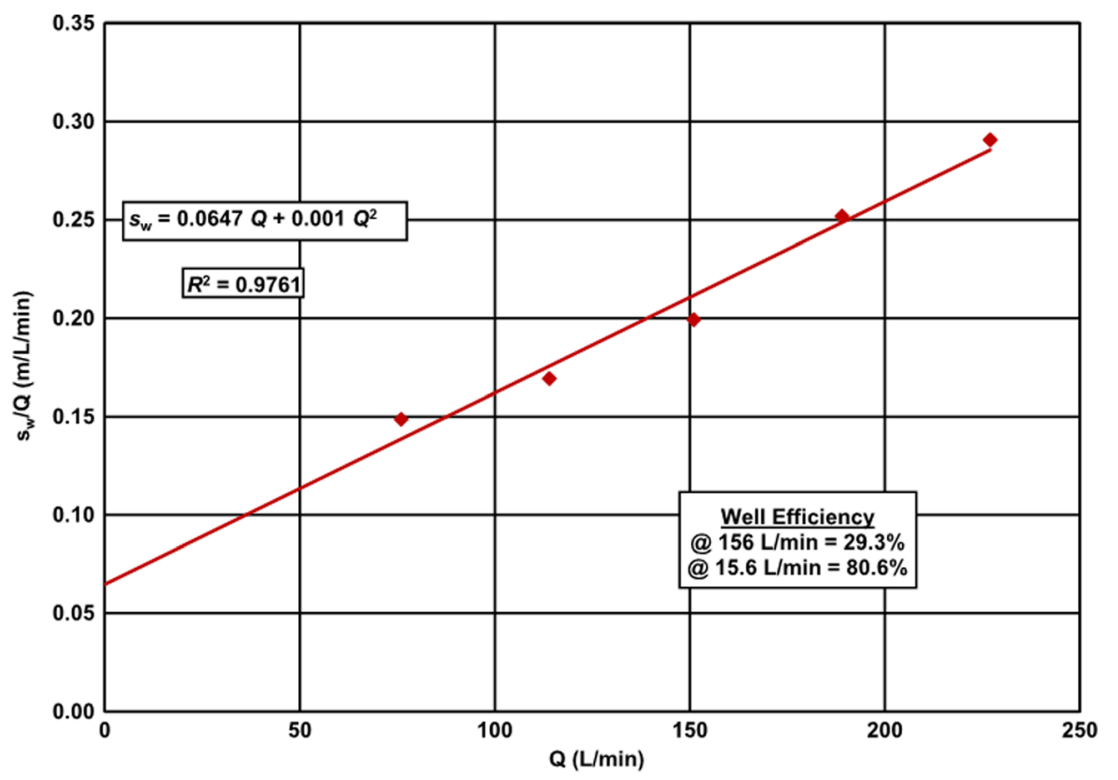


Fig. 8 Poolesville well 7: 1999 semi-log plot of drawdown data from a $72-\mathrm{h}$ and $192-\mathrm{L} / \mathrm{min}$ test, with yields derived by extrapolating to 90 days from possible IARF segments and showing the Moench leaky aquifer model best fit (with production data and lithologic description). Ls limestone, Ss sandstone, $w b z$ (single) waterbearing zone

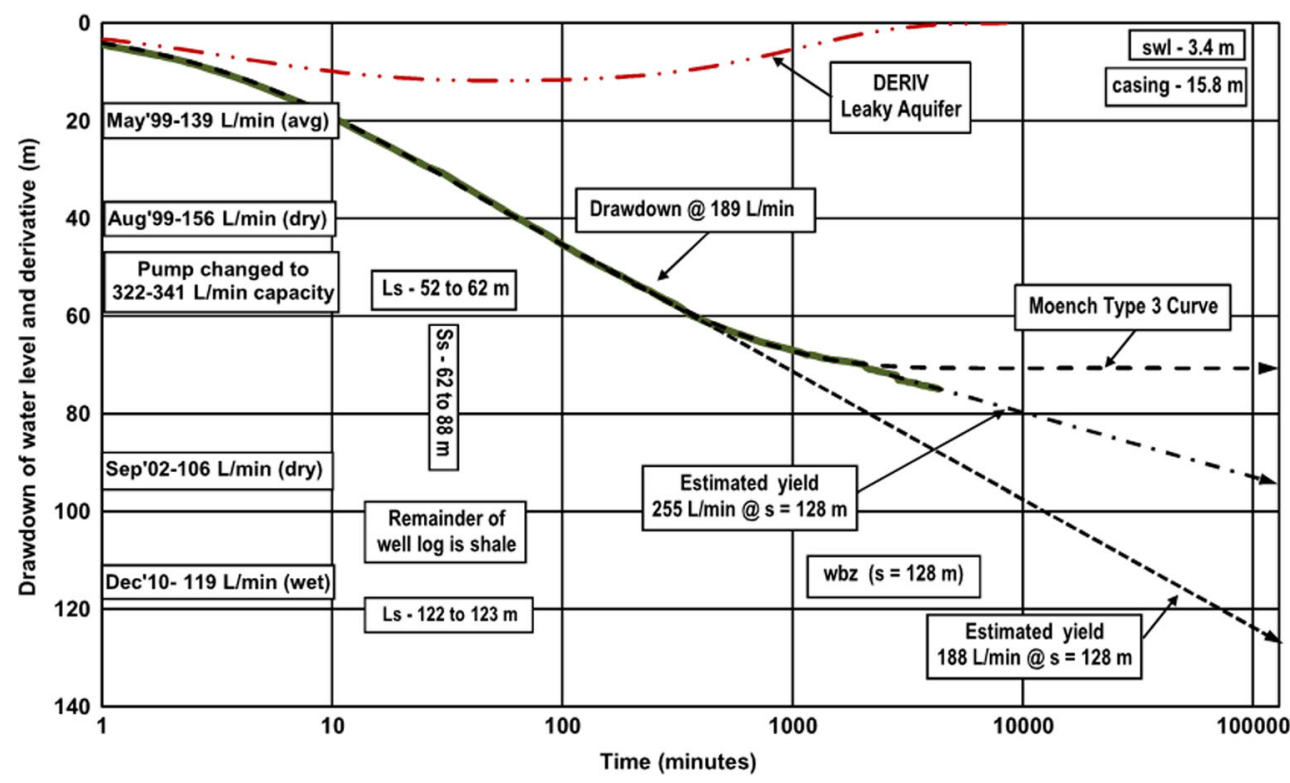

yield of $119 \mathrm{~L} / \mathrm{min}$ at a water level of $115 \mathrm{~m}$, under wet climatic conditions. This was substantially less than the $156 \mathrm{~L} /$ min that was produced during the 1999 drought with a water level of $43 \mathrm{~m}$. These data indicate that well 7 may have been damaged due to dewatering of the intermediate level limestone/sandstone unit. Two possible explanations for the reduced yield - fracture compression or mineralization - are described in detail in the 'Discussion' section.

A review of daily data during the period 1996-2001 indicated that Poolesville's system could produce about $2,100 \mathrm{~L} / \mathrm{min}$ under very wet (high water table) conditions and $1,640 \mathrm{~L} / \mathrm{min}$ during a severe drought (low water table) conditions. The change of $22 \%$ is substantially less than the $>50 \%$ decline during the drought that was noted in Emmitsburg wells 3 and 5. The lesser variation in the Poolesville yields could be that its wells were only operated to meet demand, while Emmitsburg's wells 3 and 5 were pumped continuously, which left less water in aquifer storage to supply those wells at the start of the drought. In addition, there was a lag in changes of Poolesville's well yields relative to recharge/drought events of about 4-8 weeks, which was confirmed by a dye trace study involving Poolesville well 2. This was less than the 4-month lag noted in the Emmitsburg production records, suggesting that the storage capacity of the Emmitsburg aquifer is higher than that of the Poolesville aquifer.

Poolesville's water system is operated intermittently to meet customer demand. Most of the time, the wells in use are pumped for the same specific number of hours each day. During the period from 1997 to 2000, wells 2-7 were pumped in tandem, while wells $3-5,7$ and 8 were primarily used from 2001 through 2003. During those periods, regional groundwater levels varied from record highs in
April 1997 to near record lows in December 2000. Since the wells were operated intermittently, the town's monthly production data were normalized by dividing the average of the daily use by the average number of hours pumped each day.

Figure 9 is a graph of the production from wells $2-7$ plotted against regional water levels in USGS well $50 \mathrm{~W} 4 \mathrm{C}$, located $11.8 \mathrm{~km}$ southwest of Poolesville. Initially, the average production led the groundwater levels by about 2 months, so the water use data were shifted forward to produce matching trends. This would suggest that the aquifer storage capacity at the reference well site is greater than that near the municipal well field and/or the leakage rate is less. After mid-1999, the production from the wells increased relative to groundwater levels. This change was related to the replacement of the pump in well 2, which increased its yield from 76 to $379 \mathrm{~L} / \mathrm{min}$. Using the groundwater levels as a proxy, the maximum (wet) unit production rate from the system, prior to the changing the pump, was about twice as much as the minimum (drought) rate.

After 2000, wells 2 and 6 were primarily out of service; while well 8 was then added to the system. Figure 10 is a graph of the production from wells 3-5, 7 and 8 plotted against regional water levels (USGS well $50 \mathrm{~W} 4 \mathrm{C}$ ). In that case, the production data were shifted forward 1 month to produce matching trends. Until 2003, the sets of data tracked each other well, after which the system production then declined relative to regional groundwater levels. A review of water level data from the common municipal wells in service during the two wet periods (2003 and 1997) revealed that the wells in 2003 were being underutilized. In March 2003, the water levels in wells 3, 4 and 5 were 15,11 and $15 \mathrm{~m}$, respectively; while in April 1997, the levels in wells 3, 4 and 5 were 39, 62 and 103 m, respectively. An exception was well 7, 
Fig. 9 Poolesville production data: Reported water use from Poolesville wells 2-7 and groundwater levels (GWL) in the USGS monitoring well $50 \mathrm{~W} 4 \mathrm{C}$, and 3-month moving averages, with water use data shifted forward by 2 months

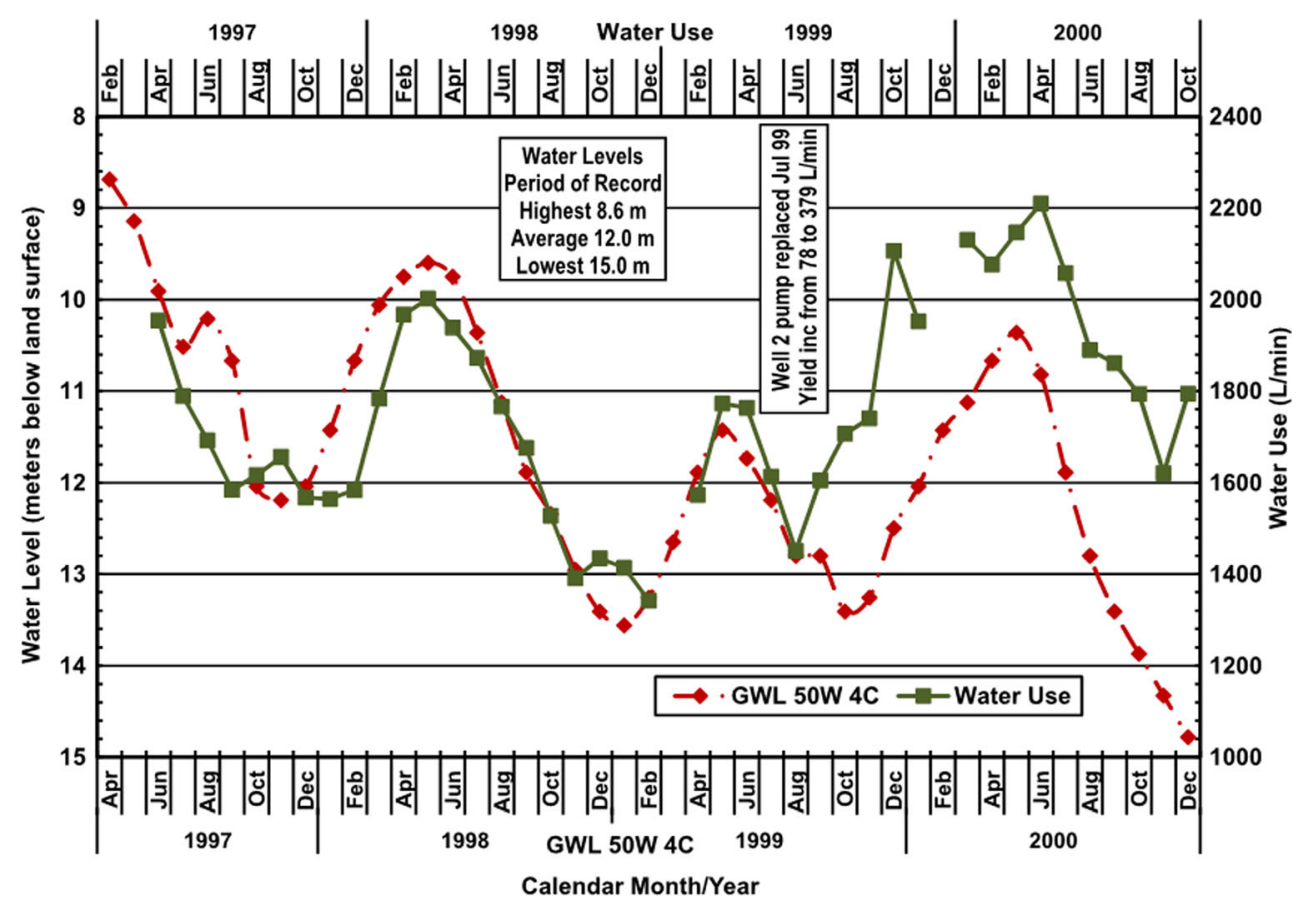

which had water levels of $63 \mathrm{~m}$ in March 2003 and $32 \mathrm{~m}$ in April 1997. This anomaly is probably related to a higher capacity pump that was installed in well 7 between the two periods, which is additional evidence that well 7 may have been damaged as a result of dewatering, and compaction or mineralization of the reservoir rock unit in the wellbore, producing a decreased yield and an increase in operating water levels.

\section{Taneytown well 13}

The city of Taneytown's well 13 was also completed in the Triassic New Oxford Formation. That well contains five water-bearing zones between 99 and $177 \mathrm{~m}$. The observed static water level of $25.6 \mathrm{~m}$ was about $15 \mathrm{~m}$ below regional water levels, which was probably due to interference with the city's nearby well 10 .
Fig. 10 Poolesville production data: Reported water use from Poolesville wells 3-5, 7 and 8 and groundwater levels $(G W L)$ in USGS monitoring well $50 \mathrm{~W} 4 \mathrm{C}$ water levels, and 3-month moving averages, with water use data shifted forward by 1 month

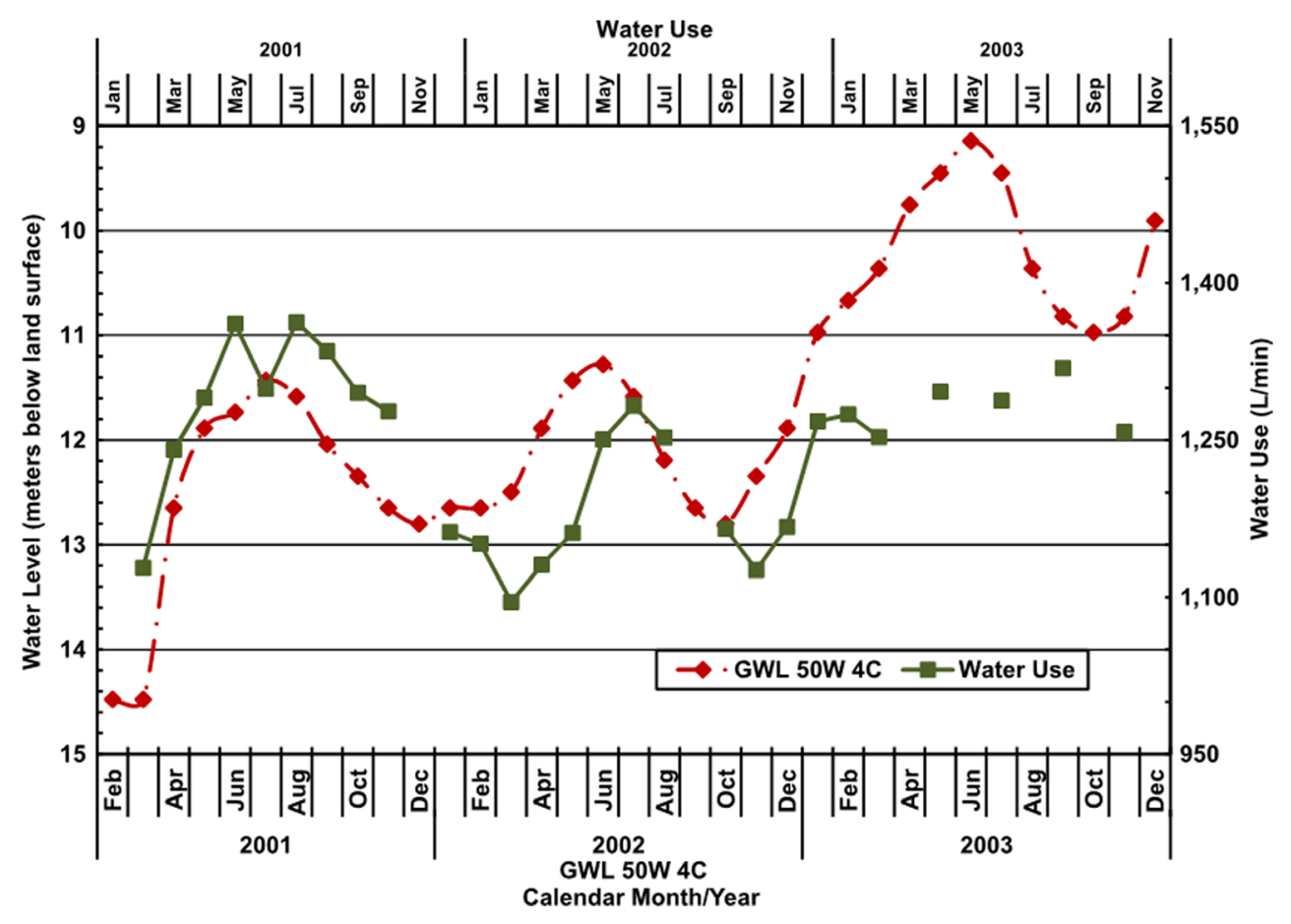


Fig. 11 Taneytown well 13: Semi-log plot of drawdown from 49-h, variable-rate step-test; data are both uncorrected and corrected for aquifer thickness $(b)$ of $50 \mathrm{~m}$. The positions of reservoir rock units and the first major water-bearing zone are shown

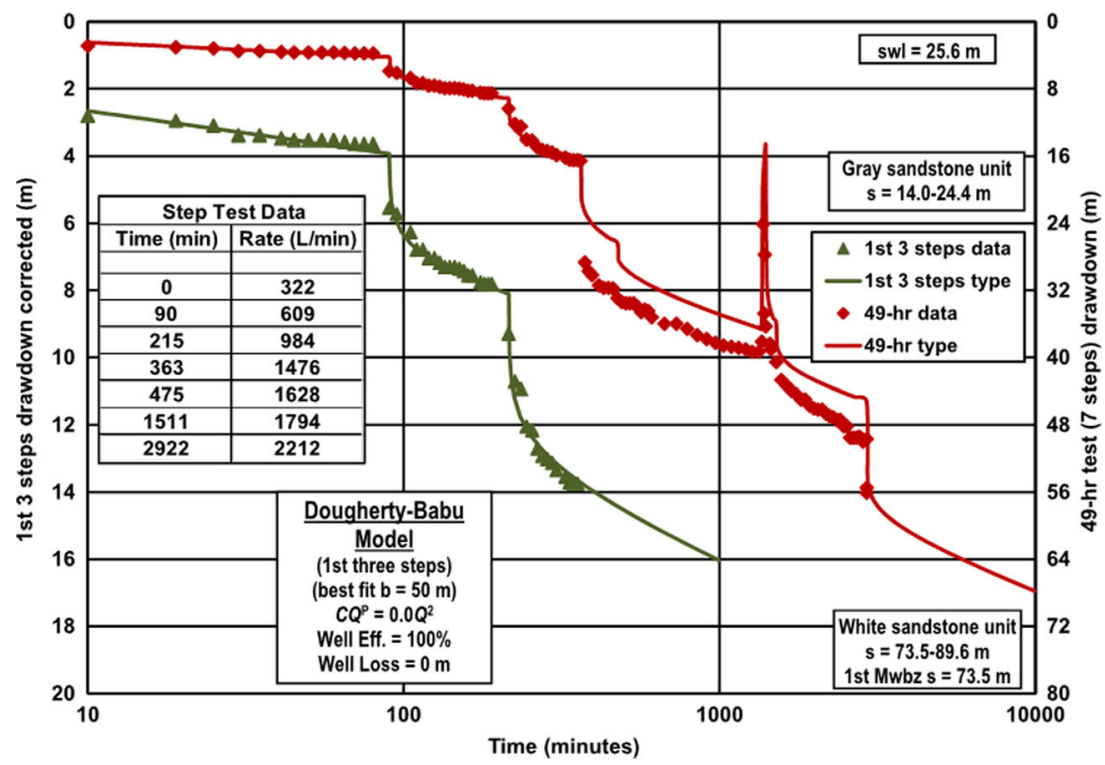

A 49-h variable-rate (average of 1,559 L/min) pumping test of well 13 was conducted in September 1985 and effectively was a long-term step-test. Figure 11 is a semi-log plot of the drawdown data from that test. When the modified DoughertyBabu model is applied to all seven steps and $b=73.5 \mathrm{~m}$, based on the drawdown to the first major water-bearing fracture in the well, it was assumed that there is a relatively poor fit to the data $\left(\mathrm{RSS}=778 \mathrm{~m}^{2} ;\right.$ mean $\left.=0.12 \mathrm{~m}\right)$. The data appeared to diverge after the first three steps, upon dewatering of a 10-mthick gray arkosic sandstone unit, the base (50 m depth) of which is located near the level where rapid changes in operating water levels had been noted. Similar gray and white sandstone units are penetrated by the city's higher capacity wells, but are absent in its lower capacity wells. Through an iterative process, the best fit $\left(\mathrm{RSS}=5.9 \mathrm{~m}^{2}\right.$; mean $=-0.005$; efficiency $100 \%$; and well loss $=0 \mathrm{~m}$ ) to the data from the three early steps was obtained using a saturated thickness of $50 \mathrm{~m}$. This is about $34 \mathrm{~m}$ deeper than the observed break in drawdown data and between the depths of the gray-and-white sandstone layers in the well. The estimated saturated thickness may represent a composite effect caused by groundwater flow from those two units. These results suggest that the drawdown to the first gray sandstone unit controls the well's yield, even though it contains no discrete water-bearing fractures.

The Cooper and Jacob (1946) method for variable-rate tests was initially used to evaluate the data, by using the specific drawdown $(s / Q)$ to produce a curve from which water levels could be extrapolated. Figure 12 is a semi-log graph of $s / Q$ versus time of the data collected during the test of well 13 . There was evidence of a break-point in the data at $45 \mathrm{~m}$ during both the pumping portion of the test and the recovery phase. Due to the variable rate, the early-time specific drawdown
Fig. 12 Taneytown well 13: Semi-log plot of specific drawdown and recovery data from a 49-h, variable-rate test; yield is derived by extrapolating deconvoluted data using the Moench dual porosity model. $G-R$ is an abbreviation for the Gringarten-Ramey model

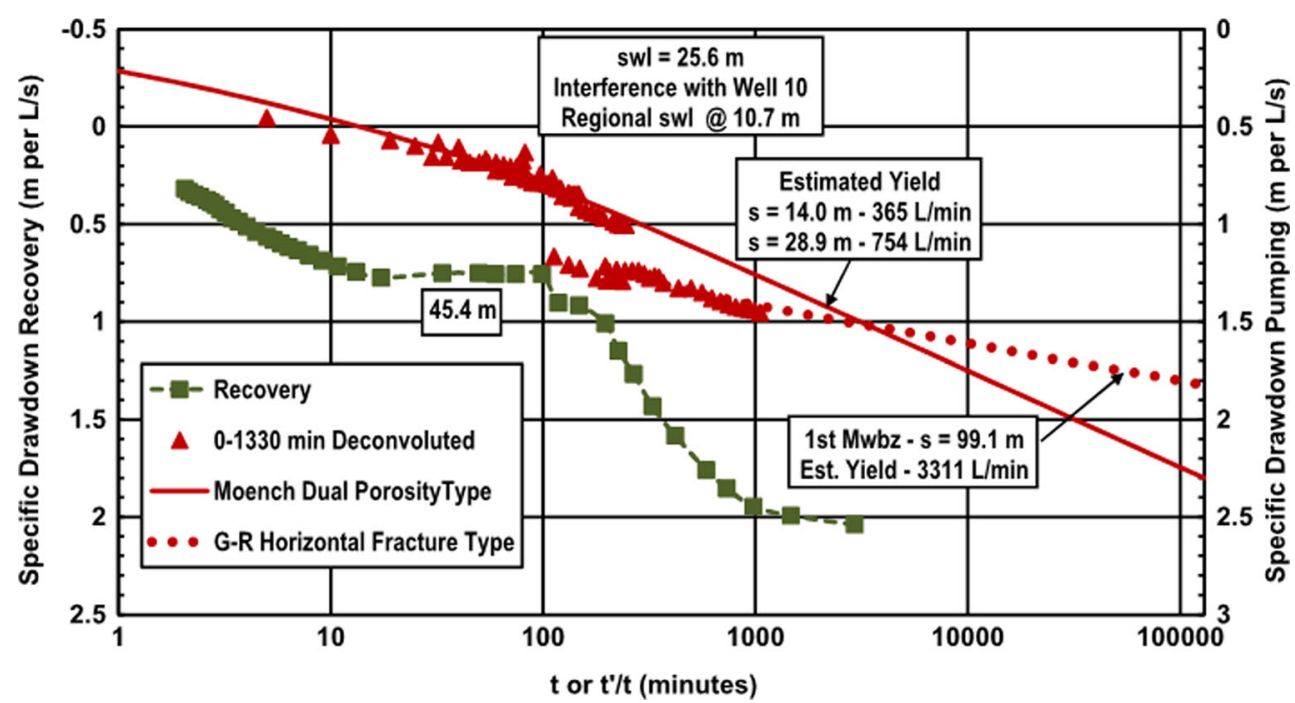


Fig. 13 Taneytown well 13: Water use and water level data from the well

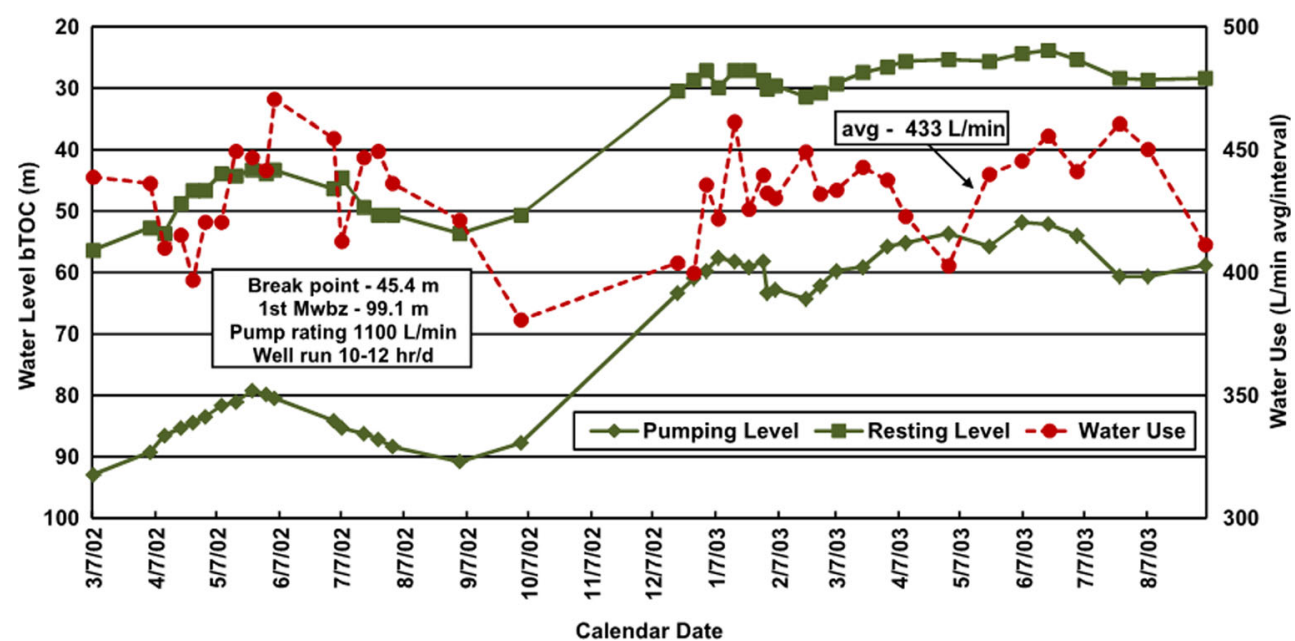

data were fairly erratic. Those data were adjusted by using the deconvolution techniques published by Birsoy and Summers (1980). The best fit to the resulting curve was the Moench dual porosity model. When the extrapolated $s / Q$ at 90 days is applied to the drawdown to the top of the first gray sandstone unit, the estimated yield is $365 \mathrm{~L} / \mathrm{min}$, but this included interference with well 10. To eliminate the effects of interference, regional water levels were used to estimate available drawdown. This produced an estimated individual yield for well 13 of $754 \mathrm{~L} / \mathrm{min}$. When the data collected after the break-point were extrapolated to the first water-bearing zone at $99 \mathrm{~m}$, by fitting a horizontal fracture curve to the data, the estimated yield is an unrealistic $3,311 \mathrm{~L} / \mathrm{min}$. Based on the last full step, the consultant's estimated yield was 1,794 L/min.

Figure 13 is a plot over time of the resting and pumping water levels and the average monthly production collected from well 13 between March 2002 and August 2003. The well was pumped during that period at a relatively constant rate of $433 \mathrm{~L} / \mathrm{min}$ average. The pumping water level in the well was about 85-90 m during the drought, which was near the first water-bearing zone. After the drought, the pumping water level rapidly recovered about 25-35 to 55-60 m, a depth near the break in drawdown data that occurred during the pumping test. The operator indicated that the well was pumped for about 10-12 $\mathrm{h}$ /day during the drought, due to the low water levels. Due to contamination by PCE (tetrachloroethylene) and other problems, it has not been feasible to perform a test to determine if well 13 could have produced more water during the drought. However, based on the limited remaining available drawdown during the drought, it is expected that water levels in well 13 would have reached the pump intake set at $105 \mathrm{~m}$, with only a modest increase in the pumping rate. If this were the case, the reliable yield of well 13 is about half of the author's estimated yield and a quarter of what the city's officials and hydrogeological consultants thought was available. This example demonstrates the importance of obtaining good operational data immediately after a well is first placed in service.

Based on the conceptual model developed in this report, two initial recovery wells were completed in the upper gray sandstone unit. Withdrawals from those wells reduced PCE levels of raw water samples taken from well 13 from an average of $12.1 \mu \mathrm{g} / \mathrm{L}(2003-2004)$ to an average of $4.7 \mu \mathrm{g} / \mathrm{L}$ (2005-2008), the latter which was below the maximum contaminant level (MCL) of $5 \mu \mathrm{g} / \mathrm{L}$. The remainder of the PCE was removed by a granulated activated charcoal treatment system. Potential follow-on recovery wells in the lower gray sandstone unit or in the discrete water-bearing zones have not been drilled to date. The well has been out of service since 2009, due to radiological contamination (adjusted gross alpha radiation). Daily dewatering of the upper gray sandstone probably formed an air gap that provided a radiation shield, resulting in lower levels in $2002(7.1 \mathrm{pCi} / \mathrm{L})$ than those in $2008(15.7 \mathrm{pCi} / \mathrm{L} ; \mathrm{MCL}=15 \mathrm{pCi} / \mathrm{L})$ when the unit was saturated, suggesting that the upper gray sandstone may be a source of the radiological contamination.

\section{Summary of additional case studies}

For details of the following case studies, refer to the ESM.

\section{Westminster Vo-tec well}

A first test produced a high yield, but excessive turbidity. The turbidity cleared after shallow weathered-zone water-bearing fractures were cased off, but there was a substantial decline in the yield during a second test. Once the well was placed in service, the initial yield equaled the estimated yield; however, the yield then declined due to a limited recharge area not evident during the aquifer tests. 


\section{Poolesville wells 1, 2, 4 and 6}

Well 1. A pseudo-equilibrium phase was induced by systematic reduction in test rate during a pumping test, resulting in an over-estimated well yield.

Well 2. The pumping test and operational data were analyzed using the methods in the present study and demonstrated that the well production had declined. The yield was then restored by replacing the well pump.

Well 4. Two pumping tests were conducted under differing climatic conditions, producing different response curves. Dewatering of a potential reservoir unit was observed during the second test.

Well 6. The present study demonstrated that the reliable yield of the well declined with time, probably due to dewatering, followed by compaction or mineralization, of a primary reservoir rock unit/water-bearing zone.

\section{Point of rocks wells $M$ and $N$}

The present study indicated that linear flow and interference occurred during pumping tests, resulting in over-estimated individual and total well yields.

\section{Thurmont wells 8 and $8 A$}

Wells 8/8A indicated high turbidity during the initial pumping test caused plugging of the well-pump-intake screen, resulting in a sharp drop in the drawdown curve, producing a response similar to dewatering of the reservoir unit. The step-test did not require correction for aquifer dewatering and indicated that the aquifer was confined.

\section{Discussion}

Even before the drought, many of the communities using groundwater supplies in the central Maryland study area frequently had to impose water restrictions due to inadequate well yields. Since the end of the drought, with application of the methods developed in the present study, none of those systems have had any significant problems related to well yields. In addition, the use of the techniques have saved those communities from the need for costly replacement wells, by increasing system operational efficiency and identifying wells in need of rehabilitation or those proven to fail prior to the construction of expensive infrastructure.

At the Karoo campus (Fig. S4 of the ESM) and Thurmont (Fig. S19 of the ESM) sites there was no evidence of aquifer dewatering during either the step or hydraulic tests. In both cases, highly permeable limestone or sandstone aquifers were overlain by impermeable clay, shale or mudstone confining units. At other sites, the results of the present study indicate that the reductions in specific capacity as discharge rate increases in fractured-rock wells may be due to factors other than turbulent flow. Pumping of fractured-rock wells under water-table conditions where there is a major reduction in saturated thickness, can introduce other head losses. This may also be the case for wells completed in leaky, semi-confined, consolidated sedimentary rock aquifers. Application of computer generated type curves achieved the best results when step-test data were corrected for the effects of dewatering, producing high well efficiencies and low well losses, at reliable sustainable yields. The only times that well efficiencies were relatively low were when well intake screens were clogged due to high turbidity/sediment levels. The base of the aquifers used to make the corrections for dewatering occurred near the depths of the transition zone in crystalline rocks and those of thin-bedded permeable units in consolidated sedimentary rocks. These transition zones or permeable units act as high porosity reservoir rocks, but may not allow direct sufficient flow of groundwater to a well because the permeability of the units and the areas exposed to wellbores are small. Non-directional macro- and micro-fractures in the matrix of the deeper portion of the aquifer may extend over a large area, which can allow efficient flow from the reservoir rocks to hydraulically connected, discrete, water-bearing fractures intersecting the wellbore.

Leakage and IARF conditions were the dominant flow regimes during most of the hydraulic tests in the present study. The responses reflect single-porosity, homogeneous, anisotropic aquifers produced by layering in weathered transition zones in crystalline rocks or sandstone/limestone units in sedimentary formations. In addition, there was one example each where single-porosity vertical and horizontal fractures controlled flow. Conversely, the modified dual-porosity Dougherty-Babu model provided the best fit to the timedrawdown data collected during the step-tests. One possible explanation for this difference is that the rock matrix usually consists of numerous blocks, which are large relative to the volume tested during the step tests, but small compared to the reservoir size, as troughs of depression expand during the longer tests. A second possibility is that the fracture networks are discontinuous. In that case, a well may intersect a local fracture system that only extends a short distance from the wellbore beyond which a radial flow regime can develop, given sufficient pumping time.

IARF and leaky aquifer responses commonly occur during fractured-rock aquifer pumping tests. Evidence indicates that two crystalline rock wellbores in the present study were open to the weathered transition zone, producing short-circuits that directly connected the weathered zone and bedrock portions of the aquifers. When a second casing was set to bedrock in the Vo-tec well, the drawdown changed from an IARF to a 
leaky aquifer response. This effect was not observed during the consolidated sedimentary rock tests, possibly because the weathered zones in those wells were thin and unsaturated.

Derivative analyses were useful in identifying IARF segments on drawdown curves, from which drawdown data could be extrapolated. If IARF was not present, then type-curve methods were used to determine the appropriate conceptual model for making predictions of well yields. The best results in this study were obtained by applying extrapolated specific capacities to available drawdowns determined by the depths to reservoir rocks, rather than to discrete, water-bearing fractures. Extrapolation of drawdowns appears to be stable when estimating reliable yields in the present study for peak or seasonal time periods (90-200 days) during a drought, when recharge is not a significant factor. Where boundaries exist or where the geometry of the aquifer is not ideal, longer tests are recommended, followed by applications of image theory or numerical calculations.

The methods developed in the present study apply best to locally layered aquifers consisting of crystalline rocks with porous weathered transitions zones and consolidated sandstone and limestone units. Because there were insufficient long-term drought production data, additional study is needed to determine the best methods for estimating yields of wells in crystalline rock units with unsaturated or absent weathered zones, consolidated siltstone and shale formations, and areas with intensive karst development.

After being placed in service, there was evidence that the yields of three consolidated sedimentary rock wells in the present study declined about 40-50\% each over time. In all three of these cases, reservoir rock units were dewatered; however, in only one case was a discrete water-bearing fracture known to have been drained. Lowering of water levels in the wells may have caused calcite precipitation to clog fractures; but, only one of the three wells, Poolesville well 7, is known to have penetrated a limestone layer. It is possible, however, that calcite cementation was present but not noted in the sandstone units of the other two wells-Poolesville well 6 and Taneytown well 13. Another possibility is that natural fractures in the wells or aquifer may have closed over time due to deformation, as water levels in the wells declined. It is likely that the drawdowns may have exceeded elastic limits of the aquifers in the vicinity of the wells, causing permanent damage to each well. Until additional research is conducted, this suggests that water levels should not drop below reservoir units, instead of relying on the commonly held precaution of limiting drawdowns to the depths of discrete water-bearing fractures. Declines of well yields could not be detected after dewatering crystalline rock reservoir units. Possible explanations are that either the relatively shallow weathered zones have adjusted to seasonal variations in water levels, calcite cementation did not occur, or that crystalline rock aquifers are much less deformable than consolidated sedimentary rock formations.
Another factor to consider is that each of the three wells with reduced yields has a substantially oversized pump installed. Kawecki (2001) mathematically compared continuous to cyclic pumping from a well using the Theis analytical model and demonstrated that continuous pumping of a well at the maximum sustainable rate produced considerably more water. In one case in the present study, Poolesville well 7 initially had a well pump that was designed to be pumped continuously at or near the maximum sustainable rate. When a higher capacity pump was installed, the daily production declined substantially. Dahl flow-control valves were installed by the town water-system personnel in that well and in well 6 . While this allowed the wells to be pumped continuously without excessive drawdowns, the production from those two wells has remained at reduced levels, which was probably related to damage caused by fracture compaction or calcite cementation.

Ideally, maximum yield is obtained when a well is pumped continuously, with the water level just above the first reservoir unit in consolidated sedimentary rocks or the first major water-bearing fracture in crystalline rocks. This probably will require a valve or variable-rate controller to be installed in the well, since most pumps tend to be over-sized. Once in service, a well should be immediately pumped at or near full capacity. In practice, however, most operators hesitate to operate their systems more than $16-18 \mathrm{~h}$ /day or about $80 \%$ of capacity. A reasonable estimate of the full capacity of a well can be made from such data, as well as provide a reasonable margin of error until the maximum reliable yield can be demonstrated.

In other studies, water balance methods have been used to determine reliable yields by calculating the available recharge within the capture zones of wells. This requires good measures of transmissivity, storage constants and recharge rates, which are difficult to obtain in fractured rock aquifers. Most fracturedrock analytical models were developed by the petroleum industry for production wells, so they generally produce good results when applied to pumping groundwater wells, but problems seem to arise when they are used to analyze observation well data. Rushton and Howard (1982) indicated that estimates of aquifer parameters from pumping tests using open observation boreholes in fractured aquifers are unreliable. Estimates of recharge are subject to considerable error, as Stuckey (2006) indicated in her study of Pennsylvania streams, where the standard error was about $22 \%$, when calculated base-flow data from basins with stream-gaging stations were applied to those without stations. Voss (2011) indicated that baseflow depends on the hydraulic conductivity around the streambed and that it is rarely well known. He further suggests that much of any recharge measured at the ground surface may discharge close to its entry point or to a nearby surface-water body and not reach the deeper aquifer of interest.

Analytical models describe relatively simple geometries, and derivative analysis techniques can help identify specific 
flow regimes. More detailed characterizations of the groundwater flow systems are only possible using data-intensive, calibrated numerical models, commonly used to identify water supplies at risk for potential contamination. Many governing authorities in the United States require some estimate of well yields for water abstraction or use permits; however, due to the large number of wells that are tested, it is presently unlikely that they will require completion of expensive, calibrated groundwater flow models to obtain such permits. They may accept uncalibrated simulation models (such as the FCmethod used in the Karoo study), with the attendant errors in estimating hydraulic parameters and recharge values. The methods developed in the present study are practical, cost effective and have produced reliable results; thus, they are more likely to be accepted by governmental agencies for use in water-use-permitting activities. They also would be especially useful in developing countries which may have limited financial resources available for water-supply investigations.

\section{Conclusions}

Derivative analysis techniques were useful in the present study for locating IARF segments on a semi-log, time-drawdown curve or, if an IARF segment was not present, determining the correct conceptual model from which drawdown data were then extrapolated. The best results were obtained by applying extrapolated specific capacities to available drawdown to permeable zones, located in the transition zone between weathered rock and bedrock in crystalline rock aquifers, or thin-bedded sandstones or limestones in consolidated sedimentary rocks. These units may not yield water directly to the wellbore, but act as reservoirs that are hydraulically connected to primary water-bearing fractures. Drawdowns below the reservoir units in the consolidated sedimentary aquifers may have caused permanent damage to wells in the present study. To protect yields, it is suggested that water levels should not drop below reservoir units in those types of wells. The discharge rate for a long-term pumping test has to be chosen carefully because it may be too low so that the drawdown does not reach the permeable units, or too high, such that dewatering is too rapid for the zone to be identified. Reservoir rocks may be better identified by extending the standard three-rate step-test to five or more steps, with progressively increasing discharge rates, while producing the maximum possible controlled drawdown.

For the cases in the present study, well efficiencies were high and well losses were minimal, when step-test data were corrected for the effects of dewatering. This was probably due to the absence of screens and gravel packs, typical for most fractured-rock wells that are open or uncased in bedrock, which can increase entrance velocities. Also, open fractures may extend some distance from each of the wells, increasing the effective radii of the boreholes. To check for evidence of the effects of aquifer dewatering, step-test data should be analyzed using deconvolution techniques and type-curve methods in lieu of arithmetic plots of specific drawdown versus discharge. Should significant well losses occur, they can be subtracted from available drawdowns to reservoir rock units when estimating reliable well yields.

Available operational data from this and other studies indicate that, when pumped continuously, the maximum yields of wells during wet periods may be 2-3 times greater than minimum drought yields. When pumped intermittently to meet demand, the ratio may be closer to 2:1. A practical method for correcting aquifer test data for climatic effects is to use such empirical data and compare the test well's static water level to the seasonal water levels in a nearby USGS or other long-term groundwater monitoring well. In this case, however, it is noted that well yields led or lagged regional groundwater levels by about 1-4 months, which appeared to be related to the differing aquifer storage capacity and/or leakage rate of the water supply well sites relative to those at the reference monitoring well sites.

Step tests and short-term, single-well, aquifer pumping tests are commonly used to determine well capacities for water system design. Where financial resources are limited, the methods used in the present study provide an alternative to, as well as help in the planning for or in support of, relatively costly programs that may include geophysical well logging, multi-well and packer/interval testing, water balance calculations and numerical analyses. Once a well is on-line, costeffective long-term operational data can be collected by water systems operators to firmly establish its yield relative to the analytical prediction. The data should be taken over a period of several years that includes a drought and the records from the well should include the daily production, the number of hours pumped each day, and the depth of any stable operating water level near the end of each daily pumping cycle.

Acknowledgements The editor Dr. Elizabeth Screaton, an anonymous associate editor, Thomas Mack and two anonymous reviewers, and the technical editorial advisor Sue Duncan, provided many useful comments and suggestions that greatly improved the content and organization of the manuscript. The management of the Maryland Departments of Natural Resources and the Environment provided support during the implementation of the test and analysis procedures used in the present study. The study was partially funded by the Maryland Department of the Environment and fulfills part of one of the objectives of a cooperative regional water-supply study in the fractured-rock areas of Maryland, details of which are contained in the USGS Science Plan, SIR 2012-5160, Fleming et al. (2012). The consulting community conducted the tests and submitted much of the data in electronic form. Water systems personnel collected and reported the long-term operational data. Dr. Malcolm Field made useful comments on an early version of the manuscript. The views expressed in this report are solely those of the author and do not necessarily reflect the views or policies the Maryland Department of the Environment. Mention of trade names does not constitute endorsement.

Open Access This article is distributed under the terms of the Creative Commons Attribution 4.0 International License (http:// 
creativecommons.org/licenses/by/4.0/), which permits unrestricted use, distribution, and reproduction in any medium, provided you give appropriate credit to the original author(s) and the source, provide a link to the Creative Commons license, and indicate if changes were made.

\section{References}

AWWA (2000) Manual M1, water rates. American Water Works Association, Denver, CO

Baiocchi A, Lotti F, Simone M, Piacentini SM, Piscopo V (2014) Comparison of pumping at constant head and at a constant rate for determining the sustainable yield of a well. Environ Earth Sci 72(4): 989-996. doi:10.1007/s12665-013-3016-5

Barker JA (1988) A generalized radial flow model for hydraulic tests in fractured rock. Water Resour Res 24(10):1796-1804. doi:10.1029/ wr024i010p01796

Billings RB, Jones CV (2008) Forecasting urban water demand, 2nd edn. American Water Works Association, Denver, CO

Birsoy YK, Summers WK (1980) Determination of aquifer parameters from step tests and intermittent pumping data. Ground Water 18(2): 137-146. doi:10.1111/j.1745-6584.1980.tb03382.x

Boulton NS (1954) The drawdown of the water table under non-steady conditions near a pumped well in an unconfined formation. Proc Inst Civil Eng 3(4):564-579. doi:10.1680/ipeds.1954.12586

Carlson MR (1999) Reservoir characterization of fractured reservoirs in western Canada. J Can Petrol Tech 38(13):1-9. doi:10.2118/99-13-64

Cooper HH, Jacob CE (1946) A generalized graphical method for evaluating formation constants and summarizing well field history. Am Geophs Union Trans 27(4):526-534. doi:10.1029/tr027i004p00526

Daniel III CC (1990) Evaluation of site-selection criteria, well design, monitoring techniques, and cost analysis for a ground-water supply in Piedmont Crystalline Rocks, North Carolina. US Geol Surv Water Suppl Pap 2341-B

Dougherty DE, Babu DK (1984) Flow to a partially penetrating well in a double porosity reservoir. Water Resour Res 20(8):1116-1122. doi: 10.1029/wr020i008p01116

Duffield GM (2007) AQTESOLV for windows version 4.5 user's guide, HydroSOLVE, Reston, VA

Fleming BJ, Hammond PA, Stranko SA, Duigon MT, Kasraei S (2012) A science plan for a comprehensive assessment of water supply in the region underlain by fractured rock in Maryland. US Geol Surv Sci Invest Rep 2012-5160, 29 pp

Gringarten AC, Ramey HJ Jr, Ragavan R (1975) Applied pressure analysis for fractured wells. J Pet Technol 27(7):887-892. doi:10.2118/5496-pa

Hammond PA, Field MS (2014) A reinterpretation of historic aquifer tests of two hydraulically fractured wells by application of inverse analysis, derivative analysis, and diagnostic plots. J Water Resour Prot 6(5):481-506. doi:10.4236/jwarp.2014.65048

Hantush MS (1960) Modification of the theory of leaky aquifers. J Geophys Res 65(11):3713-3725. doi:10.1029/jz065i011p03713

Hantush MS, Jacob CE (1955) Non-steady flow in an infinite leaky aquifer. Am Geophys Union Trans 3:95-100. doi:10.1029/ tr036i001p00095

Harned DA, Daniel CC III (1992) The transition zone between bedrock and regolith: conduit for contamination? In: Daniel CC III, White RK, Stone PA (eds) Ground water in the Piedmont. Proceedings of a conference on ground water in the Piedmont of the eastern United States. Clemson University, Clemson, SC, pp 336-348

Hydrosolve (2007) AQTESOLV ${ }^{\circledR}$ (ARCADIS, Geraghty and Miller, Inc.), version 4.50.002, Aquifer Test Analysis Software. Hydrosolve, Reston

Jacob CE (1944) Notes determining permeability by pumping tests under water-table conditions. https://books.google.com/books/about/
Notes_on_Determining_Permeability_by_Pum.html?id= XNdnGwAACAAJ. Accessed July 2017

Jacob CE (1947) Drawdown test to determine effective radius of artesian wells. Trans Am Soc Civil Eng 112(Paper 2321):1047-1064

Kawecki MW (1995) Meaningful interpretation of step-drawdown tests. Ground Water 33(1):23-32. doi:10.1111/j.1745-6584.1995. tb00259.x

Kawecki MW (2001) Comparison of continuous and cyclic pumping from a well. Ground Water 39(4):631-633. doi:10.1111/j.17456584.2001.tb02351.x

Misstear BDR, Beeson S (2000) Using operational data to estimate the reliable yields of water-supply wells. Hydrogeol J 8(2):177-187. doi:10.1007/s100400050004

Moench AF (1984) Double porosity models for a fissured groundwater reservoir with fractured skin. Water Resour Res 20(7):831-846. doi: 10.1029/wr020i007p00831

Moench AF (1985) Transient flow to a large-diameter well in an aquifer with storative semiconfining layers. Water Resour Res 21(8):11211131. doi:10.1029/wr021i008p01121

Mogg JL (1969) Step-drawdown test needs critical review. Groundwater 17(1):28-34. doi:10.1111/j.1745-6584.1969.tb01265.x

Neuman SP (1972) Theory of flow in unconfined aquifers considering delayed response of the water table. Water Resour Res 8(4):10311045. doi:10.1029/wr008i004p01031

Odeh AS (1965) Unsteady-state behavior of naturally fractured reservoirs. Soc Pet Eng J 5(1):60-66. doi:10.2118/966-pa

Otten EG (1981) The availability of ground water in western Montgomery County, Maryland. Maryland Geol Surv Rep Invest 34

Parizek RR, Siddiqui SH (1970) Determining the sustained yields of wells in carbonate and fractured aquifers. Ground Water 8(5):12 20. Correction (1971) Ground Water 9(1):51-62. doi:10.1111/j. 1745-6584.1971.tb03533.x

Piscopo V, Summa G (2007) Experiment of pumping at constant-head: an alternative possibility to the sustainable yield of a well. Hydrogeol J 15(4):679-687. doi:10.1007/s10040-006-0132-2

Renard P, Glenz D, Mejias M (2009) Understanding diagnostic plots for well-test interpretation. Hydrogeol J 17(3):589-600. doi:10.1007/ s10040-008-0392-0

Rushton KR, Howard KWF (1982) The unreliability of open observation boreholes in unconfined aquifer pumping tests. Ground Water 20(5): 546-550. doi:10.1111/j.1745-6584.1982.tb01369.x

Samani N, Pasandi M, Barry DA (2006) Characterizing a heterogeneous aquifer by derivative analysis of pumping and recovery data. J Geol Soc Iran 1:29-41

Schultz C, Tipton D, Palmer J (2005) Annual and seasonal water budgets for the Monocacy/Catoctin drainage area. Final report no. 04-04. ICPRB, Rockville, MD

Streltsova TD (1976) Hydrodynamics of groundwater flow in a fractured formation. Water Resour Res 12(3):405-414. doi:10.1029/ wr012i003p00405

Stuckey MH (2006) Low-flow, base-flow, and mean-flow regression equations for Pennsylvania streams. US Geol Surv Sci Invest Rep 2006-5130

Theis CV (1935) The relation between the lowering of the piezometric surface and the rate and duration of discharge of a well using groundwater storage. Trans Am Geophys Union 16:519-524. doi: 10.1029/tr016i002p00519

Van Tonder GJ, Botha JF, Chiang WH, Kunstmann H, Xu Y (2001a) Estimation of sustainable yields of boreholes in fractured rock formations. J Hydrol 241(1-2):70-90. doi:10.1016/s0022-1694(00)00369-3

Van Tonder GJ, Botha JF, van Bosch J (2001b) A generalized solution for step-drawdown tests including flow dimension and elasticity. Water SA 27(3):345-354. doi:10.4314/wsa.v27i3.4978

Voss CI (2011) Editor's message: Groundwater modeling fantasies - part 1, adrift in details. Hydrogeol J 19(7):1281-1284. doi:10.1007/ s10040-011-0789-z 